\title{
ФОРМУВАННЯ ІННОВАЦІЙНОЇ ОСНОВИ СИСТЕМИ СОЦІАЛЬНИХ ПРОГРАМ У ГРОМАДСЬКОМУ ЗДОРОВ'ї
}

\author{
Тернопільський національний медичний університет імені І. Я. Горбачевського МОЗ України, \\ м. Тернопіль, Україна
}

\begin{abstract}
Мета: вивчити особливості оцінки, аналізу та планування соціальних програм, які застосовують у громадському здоров'ї, розробка шляхів їх удосконалення.

Матеріали і методи. У процесі дослідження використовували загальнонаукові методи: історичний, метод порівняльного аналізу та статистичних групувань.

Результати. Політика щодо громадського здоров'я формується шляхом побудови такої системи, яка є комплексом інструментів, процедур і заходів, що реалізуються державними та недержавними інституціями для зміцнення здоров'я населення, запобігання захворюванням, подовження активного та працездатного віку, заохочення до здорового способу життя шляхом об'єднаних зусиль усього суспільства.

Соціальні програми у цій сорері покликані зреалізувати ці засоби як на державному, так і на регіональному рівнях.

Формування соціальних програм у громадському здоров'ї багато в чому має безсистемний характер - відсутні загальноприйняті стандарти публічної соціальної звітності.

У зв'язку з цим зростає актуальність вивчення основ соціальних програм, а також практичних механізмів, їх впровадження відповідно до сучасних вимог.

Дослідження сучасного стану соціальних програм у громадському здоров"ї показало наявність ряду теоретичних, методологічних, економічних, організаційних, правових проблем.

Фактичні дані свідчать, що інвестиції в громадське здоров'я загалом економічно вигідні для сектора охорони здоров'я, інших секторів та економіки в широкому розумінні з розрахунку чотириразового повернення від кожного вкладеного долара США.

Висновки. Для подальшого розвитку соціальних програм у громадському здоров'ї важливою є чітка позиція держави. Держава створила базисні умови для розвитку таких програм і ці умови мали важливе значення для початкового етапу їх становлення. Сьогодні їх уже явно недостатньо. Держава повинна створити систему регулювання таких програм, в якій знайдуть своє відображення не тільки податкові пільги, а й інші префреренції для розробників подібних програм. Особливу увагу варто приділити проблемі подолання пандемії COVID-19, яка внесла суттєві зміни в ряд перебігу хронічних та гострих захворювань.
\end{abstract}

КЛЮчОВІ СЛОВА: громадське здоров'я; соціальні програми; медичне страхування; законопроект.

Сучасне громадське здоров'я визначається як наука профрілактики захворювань, продовження тривалості життя та промоції здоров'я через організовані зусилля суспільства. Воно полягає у запобіганні захворюванням, травматизму, інвалідності та смертності, у збереженні здорового середовища і умов життя населення, популяризації здорового способу життя. Соціальні програми у цій сорері спрямовані на впровадження заходів щодо зменшення фракторів ризику захворювань та зміцнення і збереження здоров'я населення, а також належний рівень готовності до надзвичайних ситуацій природного та техногенного характеру [6].

Мета роботи: вивчити особливості оцінки, аналізу та планування соціальних програм, які застосовують у громадському здоров'ї, розробка шляхів їх удосконалення.

Матеріали і методи. У процесі дослідження використовували загальнонаукові методи: історичний, метод порівняльного аналізу та статистичних групувань.

Результати дослідження та їх обговорення. Як член Організації Об'єднаних Націй (OOH), Україна приєдналася до реалізації Цілей сталого розвитку через розробку відповідних національних стратегічних завдань, серед яких особливу увагу приділяють встановленню і розмежуванню повноважень у сорері громадського здоров'я між зацікавленими сторонами та фрормуванню програм громадського здоров'я [6].

Міністерство охорони здоров'я України створило Центр громадського здоров'я - заклад охорони здоров'я, що відповідає за збереження та зміцнення здоров'я населення, соціальногігієнічний моніторинг захворювань, епідеміологічний нагляд і біологічну безпеку, групову та популяційну профрілактику захворюваності, боротьбу з епідеміями та стратегічне управління у сорері громадського здоров'я [7]. 
У 2019 р. МОЗ України разом із Центром громадського здоров'я презентувало нову бюджетну програму та новий закон у сорері громадського здоров'я міжнародним партнерам Всесвітній організації охорони здоров'я, Європейській комісії, консалтинговій компанії «ДжіЕф-Ей Консалтинг Груп ГмбХ», Посольству США в Україні - під час засідання Координаційної ради Міністерства охорони здоров'я України з питань розвитку системи громадського здоров'я.

Європейські партнери запропонували новий Проєкт міжнародної технічної допомоги. ВООЗ і Центр контролю та профілактики захворювань (CDC) надаватимуть експертну та технічну підтримку всім ініціативам міністерства у зазначених напрямках $[1,2]$.

Бюджетна програма «Громадське здоров'я та заходи боротьби з епідеміями»

Програма передбачає комплексний підхід до аспектів громадського здоров'я - вперше у 2020 р. усі напрямки громадського здоров'я фрінансуватимуться з однієї бюджетної програми.

Імунопрофрілактика, розвиток людських ресурсів, профрілактика неінфекційних захворювань, заходи із боротьби з епідеміями, пропагування здорового способу життя, профрілактика ВІЛ, епідеміологічний нагляд за інфекційними захворюваннями - основні завдання програми.

У рамках програми передбачено придбання медикаментів для лікування ВІЛ/СНІДу, туберкульозу, гепатитів В і С, витратні матеріали та тест-системи для діагностики, супроводу і моніторингу перебігу ВІЛ-інфекції, замісну підтримувальну терапію, антиретровірусну терапію (АРВТ) для дорослих, підлітків та дітей, імунобіологічні препарати, лікарські засоби для пацієнтів 3 інфекційними захворюваннями, що супроводжуються високим рівнем летальності, а також необхідні матеріали для забезпечення розвитку донорства крові та її компонентів.

Загалом на фрінансування програми передбачено понад 3 млрд грн. Для її реалізації необхідно ухвалити Постанову КМУ про затвердження порядку використання коштів державного бюджетута накази МОЗУкраїни про затвердження переліку послуг громадського здоров'я, порядку їх надання та методики розрахунку очікуваної вартості даних послуг.

Новий законопроєкт «Про систему громадського здоров'я та забезпечення санітарноепідемічного благополуччя»

Для регулювання системи громадського здоров'я розроблено стратегічний комплексний законопроєкт «Про систему громадського здоров'я та забезпечення санітарно-епідемічного благополуччя». Він об'єднує існуючі Закони України «Про забезпечення санітарного та епідемічного благополуччя населення» та «Про захист населення від інфрекційних хвороб», а також вводить нові положення щодо регулювання системи громадського здоров'я. Зокрема, законопроєктом врегульовуються питання щодо діяльності установ із профрілактики та контролю хвороб, регіональних центрів громадського здоров'я та компетентного органу в сорері контролю за дотриманням санітарного законодавства.

Проєкт міжнародної технічної допомоги «Надання підтримки Україні у розвитку сучасної системи громадського здоров'я»

Мета проєкту - зміцнити та розширити можливості Центру громадського здоров'я МO3 України та Директорату громадського здоров'я МОЗ України за умов розвитку системи громадського здоров'я, побудувати сучасну систему безпеки крові в Україні. Реалізація проєкту здійснюється Консалтинговою компанією «ДжіЕф-Ей Консалтинг Груп ГмбХ» (GFA Consulting Group $\mathrm{GmbH}$ ) і Національним інститутом охорони здоров'я та соціального забезпечення (National Institute for Health and Welfare) і триватиме до 12 травня 2022 р. Його фрінансуватиме Європейський Союз, бюджет - близько 3 млн євро.

Проте у цих проєктах недостатню увагу приділено медичному страхуванню населення [3-5].

Потрібно акцентувати увагу на впровадженні загальнообов'язкового державного медичного страхування. Для забезпечення належного розвитку вітчизняного медичного страхування необхідним є також проведення низки заходів організаційно-правового характеру, щоб уможливило вирішення таких важливих проблемних питань:

1. Збереження конкурентного середовища на ринку добровільного медичного страхування у разі введення загальнообов'язкового державного соціального медичного страхування.

2. Забезпечення умов для повноцінного розвитку добровільного медичного страхування як доповнення до його обов'язкової форми, що забезпечувало б надання якісних медичних послуг населенню понад гарантований державою мінімум.

3. Підвищення зацікавленості роботодавців щодо збереження здоров'я своїх працівників за допомогою законодавчого закріплення економічних стимулів щодо коштів, які спрямовуватимуться підприємством на медичне страхування. Зокрема, важливим чинником такого стимулювання мають стати податкові пільги: віднесення страхових платежів із медичного страхування на валові витрати і, відповідно, зменшення оподаткованого прибутку роботодавців, а також надання податкового кредиту для фрізичних осіб.

4. Зміна вимог щодо ліцензування страховиків, які бажають працювати як в системі добровільного медичного страхування, так і в системі обов'язкового медичного страхування, для підвищення їхньої надійності. 
5. Створення уніфрікованої оптимальної системи ціноутворення на медичні послуги.

6. Забезпечення належного державного контролю за дотриманням усіма медичними установами, що працюватимуть в системі медичного страхування, єдиних законодавчо закріплених стандартів.

Незважаючи на неврегульованість питань щодо проведення медичного страхування, його питома вага у загальному обсязі страхових послуг неухильно зростає. При цьому найбільшою популярністю користується медичне страхування (безперервне страхування життя), яке займає у структурі видів медичного страхування понад $60 \%$. Необхідно звернути увагу на те, що особливістю вітчизняного ринку медичного страхування $€$ значна перевага добровільного страхування над обов'язковим.

Що стосується регіональних програм підтримки системи громадського здоров'я, вони повинні передбачати заходи 3 питань розвитку системи громадського здоров'я, лікування та профрілактики туберкульозу, ВІЛ-інфрекції/СНІДу, наркології та соціального супроводу. Їх метою $\epsilon$ розбудова системи громадського здоров'я у контексті побудови єдиної консолідованої системи громадського здоров'я для реалізації ефрективної державної політики, збереження і зміцнення здоров'я населення, збільшення тривалості та покращення якості життя, запобігання захворюванням, продовження активного працездатного віку та заохочення до здорового способу життя шляхом об'єднання зусиль органів державної влади, місцевого самоврядування і суспільства.

Передбачено, що такі програми повинні містити ряд заходів, об'єднаних за такими напрямками діяльності:

- забезпечення стратегічного керівництва в інтересах здоров'я та епідемічного благополуччя населення;

- забезпечення розвитку закладів, що працюють у системі громадського здоров'я;

- надання послуг із промоції здоров'я та організації комунікаційних кампаній;

- надання послуг з епіднагляду та оцінювання стану здоров'я і благополуччя населення;

- надання послуг, пов'язаних із соціально небезпечними хворобами ВІЛ, ТБ, наркозалежністю;

- надання послуг із реагування на надзвичайні події у сорері громадського здоров'я;

- надання послуг зі зміцнення здоров'я населення.

Для виконання завдань програми, крім управління охорони здоров'я, повинні бути задіяні підрозділи ОДА й інших відомств, територіальні підрозділи окремих центральних органів виконавчої влади, вищі медичні навчальні закла- ди I-IV рівнів акредитації, неурядові організації тощо.

Реалізація програми дасть змогу забезпечити сталий розвиток системи громадського здоров'я в регіонах, зокрема:

- запровадження інтегрованого підходу до розв'язання проблем громадського здоров'я 3 метою раціонального використання наявних людських і матеріальних ресурсів;

- отримання достовірної інформації про стан здоров'я населення в регіоні;

- створення чіткої та прозорої системи звітності про результати впровадження програм і проєктів у сорері громадського здоров'я;

- підвищення рівня поінформованості населення та органів державної влади про стан здоров'я населення, умови його збереження та пріоритети розвитку медичної галузі;

- підвищення ефективності використання бюджетних коштів у сорері громадського здоров'я та запровадження індикаторів еорективності їх використання;

- збільшення середньої тривалості життя людини;

- зниження рівня загальної захворюваності, інвалідності та смертності населення;

- зниження рівня передчасної смертності від серцево-судинних захворювань, раку, діабету і хронічних респіраторних захворювань;

- зниження рівня захворюваності й смертності від туберкульозу, ВІЛ-інфекції/СНІДУ та інших соціально небезпечних захворювань;

- зниження рівня зловживання алкоголем, неналежної фрізичної активності, вживання населенням тютюнових виробів, надмірної кількості солі та цукру тощо.

\section{Висновки}

Дослідження сучасного стану соціальних програм у громадському здоров'ї показало наявність ряду теоретичних, методологічних, економічних, організаційних, правових проблем.

Фактичні дані свідчать, що інвестиції в громадське здоров'я загалом економічно вигідні для сектора охорони здоров'я, інших секторів та економіки в широкому розумінні з розрахунку чотириразового повернення від кожного вкладеного долара США.

Для подальшого розвитку соціальних програм у громадському здоров'ї важливою є чітка позиція держави. Держава створила базисні умови для розвитку таких програм і ці умови мали важливе значення для початкового етапу їх становлення. Сьогодні їх уже явно недостатньо. Держава повинна створити систему регулювання таких програм, в якій знайдуть своє відображення не тільки податкові пільги, а й інші преференції для розробників подібних програм. Особливу увагу варто приділити проблемі подолання пандемії 
COVID-19, яка внесла суттєві зміни в ряд перебігу хронічних та гострих захворювань.
Перспективи подальших досліджень полягають у вивченні досвіду імплементації програм в українське суспільство.

\section{Список літератури}

1. Британський інститут процвітання [Електронний ресурс]. - London : Legatum institute, 2014-2017. - Режим доступу : http://www.prosperity.com.

2. Всесвітня організація охорони здоров'я [Електронний ресурс]. - Geneva : World health organization, 2014-2016. Режим доступу : http://www.who.int/gho/ru/.

3. Єрмілов В. Питання медичного страхування в сучасній Україні: пройдені шляхи і перспективи / В. Єрмілов // Соціальне страхування. - 2008. - № 1. - С. 18-21.

4. Запорожан Л. П. Медичне страхування : українські реалії та європейський досвід / Л. П. Запорожан, Л. І. Патра, М. С. Феш // Громадське здоров'я в соціальному і освітньому просторі - виклики сьогодення і перспективи розвитку : матеріали Першого міжнародного україно-німецького симпозіуму з громадського здоров'я, 25-26 вересня 2019 р. Тернопіль : ТНМУ. - С. 50-53.

5. Місце медичного страхування в системі охорони здоров'я [Електронний ресурс]. - Режим доступу : rak-r-kovalskak-pace-of-insurance-medicine-in-security-system-of-health_14278.pdf.

6. Розробка та фрінансування регіональних і місцевих програм громадського здоров'я : операційний посібник [Електронний ресурс] / В. Ляшко, Н. Півень, М. Брага та ін. // Центр громадського здоров'я. - Режим доступу : http:// www.phc.org.ua.

7. URL : https://moz.gov.ua.

\section{References}

1. (2014-2017). Brytanskyi instytut protsvitannia [British Institute of Prosperity]. London. Legatum institute. Retrieved from: http://www.prosperity.com [in Ukrainian].

2. (2014-2016). Vsesvitnia orhanizatsiia okhorony zdorovia [World Health Organization]. Geneva: World health organization. Retrieved from: http://www.who.int/gho/ru/.

3. Yermilov, V. (2008). Pytannia medychnoho strakhuvannia v suchasnii Ukraini: proydeni shliakhy i perspektyvy [Questions of medical insurance in modern Ukraine: ways and prospects]. Sotsialne strakhuvannia - Social Insurance, 1, 18-21 [in Ukrainian].

4. Zaporozhan, L.P., Patra, L.I., Fesh, M.S. (2019). Medychne strakhuvannia: ukrainski realii ta yevropeyskyi dosvid [Medical insurance: Ukrainian realities and European experience]. Materialy pershoho mizhnarodnoho Ukraino-nimetskoho sympoziumu z hromadskoho zdorovia «Hromadske zdorovia v sotsialnomu i osvitnomu prostori - vyklyky siohodennia ta perspektyvy rovytku» - First International Ukrainian-German Symposium on Public Health "Public health in the social and educational space - the challenges of today and prospects for development". (pp. 50-53). Ukrmedknyha, TNMU, Ternopil [in Ukrainian].

5. Mistse medychnoho strakhuvannia $v$ systemi okhorony zdorovia [Place of health insurance in the health care system]. Retrieved from: rak-r-kovalska-k-pace-of-insurance-medicine-in-security-system-of-health_14278.pdf. [in Ukrainian].

6. Lyashko, V., Piven, N., Braga, M. Rozrobka ta finansuvannia rehionalnykh i mistsevykh prohram hromadskoho zdorovia. Operatsiinyi posibnyk [Development and funding of regional and local public health programs. Operational manual]. Tsentr hromadskoho zdorovia - Public Health Center. Retrieved from: http://www.phc.org.ua [in Ukrainian].

7. Sait ministerstva okhorony zdorovia [Website of the Ministry of Health]. Retrieved from: https://moz.gov.ua.

\section{FORMATION OF THE INNOVATIVE BASIS OF THE SYSTEM OF SOCIAL PROGRAMS IN PUBLIC HEALTH}

L. P. Zaporozhan, N. O. Kravets, D. V. Vakulenko

I. Horbachevsky Ternopil National Medical University

Purpose: to study evaluation features, analysis and planning social programs which used in public health and development ways to improve them.

Materials and Methods. In the process of research the general scientific methods of research were used: historical, method of comparative analysis, and statistical groupings.

Results. Public health policy is formed by building a system that is a set of tools, procedures and measures implemented by governmental and non-governmental institutions to promote public health, prevent disease, prolong active and working age, promote a healthy lifestyle through united efforts of the whole society.

Social programs in this area are designed to implement these tools at the state and regional levels.

The formation of social programs in public health is largely unsystematic -there are no generally accepted standards of public social reporting. In this regard, the urgency of studying the basics of social programs, as well as practical mechanisms, their implementation in accordance with modern requirements is growing.

The current state of social programs in public health research has shown the presence of a number of theoretical, methodological, economic, organizational, legal problems.

Evidence suggests that investing in public health is generally cost-effective for the health care sector, other sectors, and the economy in a broad sense, with a fourfold return on every US dollar invested. 
A clear position of the state is important for the further development of social programs in public health. The state created the basic conditions for the development of such programs and these conditions were important for the initial stage of their formation. Today they are not enough.

Conclusions. The state should create a regulation system of such programs, which will reflect not only tax benefits, but also other preferences for developers of such programs. Particular attention should be paid to overcoming the COVID-19 pandemic, which has made significant changes in a number of chronic and acute diseases.

KEY WORDS: public health; social programs; health insurance; legislation.

Рукопис надійшов до редакції 23.06.2020 р.

Відомості про авторів:

Запорожан Лариса Петрівна - кандидат географічних наук, доцент кафедри громадського здоров'я та управління охороною здоров'я Тернопільського національного медичного університету імені І. Я. Горбачевського МО3 України; тел.: +38(0352) 52-72-33.

Кравець Наталія Орестівна - кандидат технічних наук, доцент кафедри медичної інформатики Тернопільського національного медичного університету імені І. Я. Горбачевського МОЗ України; тел.: +38(0352) 52-09-90.

Вакуленко Дмитро Вікторович - доктор біологічних наук, завідувач кафедри медичної інформатики Тернопільського національного медичного університету імені І. Я. Горбачевського МОЗ України; тел.: +38(0352) 52-09-90. 